\title{
Ideology, Materiality, and Counterpublicity: William E. Simon and the Rise of a Conservative Counterintelligentsia
}

Robert Asen

As a conceptual term, "counterpublic" serves scholarship best when contributing to a critical-theory project, which means that particular constellations of materiality and ideology may bolster some calls for counterpublicity while gainsaying others. This may be investigated by examining how a text upholds or betrays an advocate's values, seeking out textual markers of access and influence that belie claims of marginalization, and assessing whether an advocate's discourse implicitly or explicitly widens or narrows discursive space for others. From this perspective, although William Simon claimed that pro-business advocates had been excluded from public debates in his 1978 book A Time for Truth, he nevertheless asserted a commitment to negative liberty that discounted potentially conflicting values in a pluralistic society, evidenced strong financial and political connections as well as a patrician background and bearing, and restricted discursive space for others.

Keywords: Counterpublic; Ideology; Economics; William E. Simon; Public Sphere

The function of a counterintelligentsia is, above all, to challenge that ideological monopoly: to raise the unnamed issues, to ask the unasked questions, to present the missing contexts, and to place a very different set of values and goals on the public agenda.

William E. Simon, A Time for Truth

For scholars of the public sphere, the above epigraph may seem both familiar and strange. Its familiarity arises from textual features consistent with conceptualizations of counterpublicity. Referencing an "ideological monopoly," it names an exclusion of

\footnotetext{
Robert Asen is Professor in the Communication Arts Department at the University of Wisconsin-Madison. The author thanks John Lucaites and the anonymous reviewers for their insightful contributions. Correspondence to: University of Wisconsin-Madison, Communication Arts, 821 University Avenue, Madison, WI 53711, USA. Email: rbasen@wisc.edu
} 
particular perspectives from discursive forums. Enumerating "unnamed issues," "unasked questions," and "missing contexts," it suggests unrecognized and unmet needs and interests of individuals and groups that a counterintelligentsia may represent in broaching these topics. Further, it expresses a resolve to overcome exclusions in seeking to "place a very different set of values and goals on the public agenda." The strangeness of this epigraph arises when we consider its source: William E. Simon. Simon served as treasury secretary in the Nixon and Ford administrations. Prior to his official appointments, Simon worked as a senior partner and member of the executive committee of Salomon Brothers, a prominent Wall Street investment firm. After leaving government service, he assumed the presidency of the John M. Olin Foundation, an influential source of funding for conservative institutions and ideas. Simon also held seats on the boards of corporations such as Xerox, Citibank, and Halliburton, and think tanks like the Heritage Foundation and the Hoover Institution.

The peculiarity of Simon's call presents a problem for public sphere scholars. His articulation of exclusion seemingly fits our theories well, and yet, by many measures, Simon enjoyed considerable access and influence in business, social, and political circles. How, then, should we treat this call and similar cases? Foregrounding textual features, should we reluctantly admit that putatively privileged people may invoke counterpublicity just as well as marginalized and oppressed individuals and groups? Or, highlighting positions and power, should we disqualify Simon as a counterpublic imposter, an inauthentic claimant invoking exclusion to entrench his already considerable privilege? As these questions suggest, this case raises the issue of whether we ought to theorize "counterpublic" as a neutral concept in relation to materiality and ideology, or whether these considerations ought to inform our understanding of the discourse of counterpublics and their interactions with wider publics.

Simon's call constitutes a potentially illuminating case for this investigation, since he played an important role in resurgent conservative activism, and his call implicates important conceptual issues. Although not as well known as advocates like Milton Friedman and Irving Kristol, Simon articulated a coherent vision of a reinvigorated conservative political network that included think tanks, media organizations, and policy actors. Further, Simon bridged policymaking, business, and activist networks, developing efficacious strategies in each realm and making connections among them. ${ }^{1}$ Through his efforts, Simon enabled the participation of innumerable others in wide-ranging public forums. Conceptually, Simon's call challenges unexamined assumptions of counterpublic theory. Scholars have figured the relationship of counterpublicity, materiality, and ideology implicitly by focusing on left-leaning and socioeconomically marginalized individuals and groups. ${ }^{2}$ We may attribute this tendency to the convergence of critical interest in progressive social change and the orientation of scholarship signaled by the early modification of "counterpublic" with "subaltern" in the work of Nancy Fraser and others. ${ }^{3}$ Simon and similarly situated advocates invite public sphere scholars to consider whether we wish to endorse 
explicitly this implicit focus, raising questions about the kinds of normative judgments that ought to inform our scholarship.

My position is that "counterpublic," as a conceptual term, serves scholarship best when contributing to a critical-theory project, which means that particular constellations of materiality and ideology may bolster some calls for counterpublicity while gainsaying others. In contrast, if we treat counterpublic as a neutral term in relation to materiality and ideology, then the concept loses its critical purchase and instead forwards a decontextualized and dehistoricized perspective that fails to account for the ways in which relations of power and symbolic and material resources influence the production, circulation, and reception of discourse in the public sphere. Appreciating these discursive processes requires scholars to balance textual assertions with critical judgment when considering calls for counterpublicity. We cannot simply dismiss Simon - an avowed conservative, a financially successful investment banker, and an influential political actor-or similarly situated advocates because of their privileged socio-economic standing or conservative ideologies. Doing so would advance a discourse methodology a priori that oddly devalues discourse, since we could reach critical conclusions without considering an advocate's discourse. Further, this approach would elide critical judgment through unreflective application, requiring us simply to supply "data" for a pretested formula. And yet we must critically evaluate calls for counterpublicity, which may be done by considering texts in context and unpacking the rhetorical dynamics of the texts themselves. If we regard material (dis)advantage and ideological perspective as neutral, we risk ceding our critical judgment to the most transparent claims of the text, which reduces our work to paraphrase and leaves us unable to pursue important normative questions. Balancing text and judgment means that we must heed calls for counterpublicity even as we critically evaluate them.

Public sphere scholars may undertake this critical project by approaching calls for counterpublicity as starting points of investigations that analyze how, among other considerations, an advocate's discourse may signal its own privilege. As a critical term, privilege is a relational, historicized concept indicating differential access to various material and symbolic resources informing interactions in a multiple public sphere. The relational quality of privilege appears in its denotative meaning as a right or advantage enjoyed by an individual or group "beyond the usual rights or advantages of others." 4 As this definition suggests, we should not understand privilege as a fixed or isolated aspect of identity - privilege invokes both an agent who enjoys an advantage and others who do not benefit. In this way, issues of materiality raise relative, rather than absolute, standards of judgment. Further, we can look to history to understand how relations of privilege have been shaped and sustained. In the United States, class, race, gender, and sexuality have not functioned as abstract or intrinsic advantages, but have been codified through laws and institutions, enforced through social practices, and justified in official and vernacular discourses. ${ }^{5}$ Counterpublic scholarship has investigated historical struggles, examining people's efforts to overcome disadvantages and (less frequently) maintain advantages. 
Starting points orient a critical analysis, suggesting key terms and research questions and indicating particular constellations of text and context. The point is not to construct the notion of counterpublic as a category and determine whether an advocate's call falls inside or outside of it, but to consider how an advocate calls for counterpublicity and how, in some cases, an advocate may articulate their own privilege. In this essay, I argue that critics may discern privilege by examining how a text upholds or betrays the values advanced by an advocate, seeking out textual markers of access and influence that belie claims of marginalization, and assessing whether an advocate's discourse implicitly or explicitly widens or narrows discursive space for others. Attending to values enacts a process of immanent critique, drawing on a tradition of critical theory to offer a historically grounded judgment. Examining textual markers comports with the recognition that no speaking position is neutral, and that discourses bear the imprints of advocates' life-worlds. Surveying discursive space draws on the critical spirit of counterpublic theory, which gleans insights from advocates' efforts to circulate alternative discourse norms and practices in wider public spheres.

This essay proceeds in three sections. First, developing a critical perspective on ideology and materiality, I amplify my proposals for discerning privilege in calls for counterpublicity. With respect to my key terms, I argue that scholars should employ a conception of ideology emphasizing values, programs, and contestation, and we should recognize a critical distinction between discourse and its material conditions. Second, I detail the context of Simon's call for counterpublicity. Writing in the economically uncertain 1970s, Simon drew on a growing public hostility toward government, a tradition of laissez-faire economic thought, and an emergent network of conservative think tanks. Third, analyzing A Time for Truth, I argue that Simon asserted a value of negative liberty that discounted potentially conflicting values in a pluralistic society, evidenced strong financial and political connections as well as a patrician background and bearing, and restricted discursive space for others.

\section{Critically Examining Counterpublicity}

In the vernacular of US political culture, ideologies are typically cast as liberal versus conservative. This framing warrants healthy skepticism, since political commentators often characterize these two options as an exhaustive cataloguing of political belief and as a mutually exclusive choice. Media references to "red states" and "blue states" constitute a conspicuous and evocative representation of the potentially pernicious consequences of reductionism. However, oversimplification notwithstanding, this vernacular use holds critical potential insofar as it connects ideology to political values and programs and attends to contests among political actors. Liberals and conservatives - and, we should add, libertarians, communitarians, and others - wish to see their values affirmed in public policies, and, as history demonstrates, they will often fight for policies deemed important enough. Ideology, then, serves counterpublic theory best when we regard it as a strategic set of claims, values, and beliefs that advocates may invoke to build collectives, forge alliances, and highlight 
differences. ${ }^{6}$ This definition comports with counterpublic theory's interest in moments of (attempted) social change: drawing on markers of race, gender, class, sexual orientation, and others, advocates act with the knowledge that there are important differences between themselves and their antagonists, and they do not wait for magnanimous actions from their opponents to produce ameliorative change.

This view of ideology complicates facile oppositions of conflict and consensus in our conceptual models of the public sphere, since both qualities inform interactions among advocates. Chantal Mouffe makes this point in her "agonistic model of democracy." As her terminology suggests, Mouffe highlights contest and conflict in theorizing democracy, building from her assertion that "power is constitutive of social relations." Neither inherently emancipatory nor oppressive, power serves democracy when it curbs a person's ability to "attribute to herself or himself the representation of the totality [of society] and claim to have the 'mastery' of the foundation." However, conflict requires some common commitments, as the ethical import of democratic practice promises to "transform antagonism into agonism." Successful democracies sustain a "conflictual consensus," which requires "allegiance to the values which constitute its 'ethico-political principles," even as these principles obtain salience through different and conflicting interpretations. ${ }^{7}$ A view of conflict and consensus as contingent, relational qualities of human activity underscores the role of ideology in achieving these ends. Drawing on differently shared and weighted values, ideologies serve as the vehicles for circulating alternative political interpretations and positions. For example, ideologically informed visions of the polity as an interdependent community or an aggregation of autonomous actors underlie citizens' support of and opposition to many policy proposals.

Realizing the critical potential of counterpublic theory requires not just a strong connection among ideology, values, and contestation, but critical judgments assessing how counterpublicity may promote or hinder progressive democratic agendas. In taking this position, I risk the charge that I am promoting criticism that merely confirms the biases of many public sphere scholars. Answering this concern requires situating the critical import of counterpublic theory historically rather than essentially. My reading of the literature is that its primary focus on progressive causes and groups represents a situated, historical argument. Many twentieth- and twenty-first-century advocates for social change in the US have espoused progressive causes, seeking to expand practices of democracy so as to welcome greater numbers and types of citizens into engaged public forums. Conservative groups-such as the John Birch Society, Simon's own think-tank movement, and, more recently, local militias - have generally reacted against progressive gains, upholding a putatively more virtuous, past America compromised by the incursions of suspicious others. ${ }^{8}$ In a rare case of scholarly examination of conservative calls for counterpublicity, Kristy Maddux discerns this dynamic in the anti-suffrage and STOP ERA movements. ${ }^{9}$ Both movements, with varying degrees of success, fought to uphold the status quo against expanded rights and opportunities for women. Unfortunately, Maddux does not extend this observation to a critical examination of conservative counterpublicity itself. Rather, she accepts as given the status of conservative counterpublics as a 
distinct "class" of study. However, the success of pro- and anti-suffrage movements, for example, held decidedly different implications for the expansion and constriction, respectively, of discursive space, offering grounds for differing critical judgments.

Taking a progressive stance means invoking public sphere theory as a critical theory and investigating emancipatory possibilities and oppressive practices in public and counterpublic spheres. If we shy away from this inquiry, our concepts become abstract categories applied without regard to context. Extending this observation to global politics, Shalini Randeria argues that the emancipatory aspirations of public sphere theory illuminate the neoliberal confluence of markets and democracy over the past three decades, which has produced a "hollowed out" vision of democracy as the "rule of law." Randeria argues: "Democracy cannot simply imply putting in place legal norms ... for the functioning of markets but must involve broad political participation." A weakened theory of the public sphere leaves scholars unable to ask how participation may be expanded, and with what consequences. Whereas a critical public sphere theory "enables us to ask questions about equality of access or raise issues of legitimacy and political efficacy," delinking theory and context "evade[s] question[s] of power differentials and thus dovetail[s] well with neoliberal policy prescriptions." ${ }^{10}$ Further, as Slavko Splichal reminds us, a critical theory of the public sphere resonates with the historical development of publicity as a critical concept. Enlightenment thinkers construed publicity as "a critical impulse against injustice, based on the secrecy of state actions and as an enlightening momentum, substantiating the 'region of human liberty."'11 Since its early articulation, publicity has functioned as a critical term. My call to account for ideology represents an assessment of the critical value of publicity in our contemporary political climate.

To this understanding of ideology, we need to add a conception of materiality that places discourse in relation to the material conditions from which it arises and that it engages. Exhibiting a mutually informative relationship, discourse appears amid particular conditions that it potentially reconfigures. ${ }^{12}$ Pursuing this relationship may offer insights into advocates' relative privilege in a multiple public sphere, while emphasizing its relational quality may keep scholars from either glossing over inequalities or treating discourse as epiphenomenal. With respect to inequality, it matters, for example, whether Simon the successful investment banker or someone who cleans the offices at Salomon Brothers claims exclusion from wider discursive forums; critical analyses may explicate how these differences matter. If we lose sight of the relationship between discourse and its material conditions, we lose sight of these differences. However, in terms of epiphenomena, we cannot reduce discourse to a simple expression of material conditions, since this approach would imply that discourse matters only as a proxy for "deeper" phenomena.

Recent interest in text-based publics risks occluding the relationship of discourse and material conditions. Along these lines, Michael Warner has articulated a conception of a public "that comes into being only in relation to texts and their circulation." Whereas Mouffe develops a perspective highlighting contest and social change, Warner expects less of members of a public, maintaining that a public is constituted through "mere attention." Indeed, Warner rejects dialogic models of the 
public sphere, charging that these approaches place too much weight on "argument" and "polemic." Warner retorts that public discourse "goes far beyond the scale of conversation or discussion to encompass a multigeneric lifeworld organized not just by a relational axis of utterance and response but by potentially infinite axes of citations and characterization." ${ }^{13}$ While we should not limit publics to dialogue, we need not accept the false choice Warner presents between dialogue and circulation. Publics manifest both through specific conversations between citizens and through texts circulating in mass media and new media. Some new media forms, like political blogs, combine dialogue and circulation by enabling readers to discuss posts with each other. ${ }^{14}$ In forcing a choice, Warner exhibits a remarkable blindness to his own intellectual inclinations. An exclusively text-based model of publics fits Warner's literature background and his interest in eighteenth-century British pamphlets, but this model cannot cover the range of public sphere scholarship.

Warner explicitly notes the implications of his approach: "[I]t is not clear that all counterpublics are composed of people otherwise dominated as subalterns." Instead, Warner holds that counterpublics "are 'counter' to the extent that they try to supply different ways of imagining stranger sociability and its reflexivity." That is, a counterpublic offers participants alternative ways of constituting relations with others, but ideological orientation and socioeconomic standing do not appear to inform the meaning of these alternatives. However, a crucial tension complicates the apparent openness of Warner's account, as he writes: "Dominant publics are by definition those that can take their discourse pragmatics and their lifeworlds for granted, misrecognizing the indefinite scope of their expansive address as universality or normalcy." 15 This definition raises a question concerning which social forces contribute to a sense of taken-for-grantedness and normalcy. From Rita Felski and Nancy Fraser onward, counterpublic theorists have pointed rightly to relations of power and social, political, and economic inequalities. Fraser, for example, develops the notion of counterpublics for "stratified societies," so that people excluded from wider publics may develop forums to "undertake communicative processes that were not, as it were, under the supervision of dominant groups." " More recently, Daniel Brouwer has argued that "counterpublic" as a concept "requires recognition of resource disparities among social actors, a recognition that ought to be increasingly called for in communication studies." This approach foregrounds the links between material and cultural disparities and rhetorical practices, holding that scholarship should explain "how various qualities and quantities of various resources delimit the available means of persuasion." ${ }^{17}$ In effect, Brouwer urges scholars to consider calls for counterpublicity in context, which gainsays exclusive attention to texts and circulation.

While Warner undervalues the role of material conditions in shaping relations between publics and counterpublics, others have placed too much weight on material conditions. An example of this is a recent essay by Dana Cloud, in which she argues for a class-based model of the public sphere and charges contemporary theorists with promoting a desert(ion) of the real in their attention to the constitutive power of discourse. This perspective appropriately holds that a distinction between discourse 
and material conditions creates a critical space for ameliorative social action, but it also presumes a relationship that positions "reality" as the adjudicator of discursive conflict. Cloud writes: “[A] political discourse's fidelity to a working class public's interests is tested by real experience." 18 She cautions readers against interpreting this statement as advocating a simple reflection theory of discourse and reality, since advocates must convincingly explain reality in ways that attribute agency to rhetors and judgment to audiences. Still, reality appears as the testing ground of discourse, promising that disputes ultimately may achieve a resolution outside of discourse, as positions may be judged by their proximity to objective class relations. However, reality does not speak, and we understand our experience through language and other symbols. ${ }^{19}$ We may accept inequality as the inevitable outcome of a skills gap among workers, or we may see inequality as a sign of fundamental economic problems.

To account for the ways in which ideology and materiality situate calls for counterpublicity, we need to consider how, if at all, texts articulate their own privilege. We may pursue this analysis, first, by subjecting the values espoused by a text to a process of immanent critique to see whether the text upholds or betrays its values. For instance, as I explain below, Simon championed "freedom" in his defense of the businessperson marginalized by a powerful liberal elite. In Simon's view, this core American value would disappear altogether if businesspeople did not ally with a counterintelligentsia to reclaim threatened American traditions. Given the prominence of freedom in Simon's call for counterpublicity, we may properly ask whether he attributed freedom to others or whether his program of political action limited the freedom of others. Historicizing our critique finds the values for change within the social world reconstituted by the text. ${ }^{20}$ In a similar spirit, Nancy Fraser advocates a method of immanent critique in scholarly investigations of a transnational public sphere. She urges a "critical-theoretical approach that seeks to locate normative standards and emancipatory political possibilities precisely within the historically unfolding constellation." 21 Extending this perspective to discourse practices, Michael Walzer holds that social criticism utilizes immanent critique to challenge "the leaders, the conventions, [and] the ritual practices of a particular society ... in the name of values recognized and shared in that same society." 22 Dr. Martin Luther King, Jr. exemplified the practice of social criticism when he explained that marchers had traveled to Washington, DC, in 1963 to cash a check issued in the nation's founding documents.

We also may assess privilege by seeking out textual markers that signal its existence. This approach draws on the critical recognition that no speaking position is neutral, and that all speaking positions reveal interests, experiences, and worldviews. In this way, an individual's experience of discourse and materiality imposes constraints on one's textual persona. Identity may emerge socially as a fluid, contingent construction, but we do not create self-representations from a tabula rasa. As Judith Butler contends, performances of gender identity constitute "improvisation within a scene of constraint." Butler notes that one's gender sometimes may appear as "something that I author." And yet gender is not freely constituted: "[T]he terms that make up one's own gender are, from the start, outside oneself, beyond oneself in a sociality 
that has no single author." 23 These constraints on identity inform our interactions with others. As Linda Alcoff explains, critical scholars have shown that where one speaks from "affects the meaning and truth of what one says, and thus ... one cannot assume an ability to transcend one's location." Varying social locations differently advantage and disadvantage participants in public and counterpublic spheres. Alcoff notes that particular social locations have an "epistemically significant impact on that speaker's claims and can serve either to authorize or disauthorize one's speech." ${ }^{24}$

If individuals always speak from somewhere, then these locations leave their marks on an advocate's discourse, producing tensions in some calls for counterpublicity. At certain moments in privileged texts, an advocate may construct an explicit argument claiming marginalization. However, this guise cannot be maintained consistently throughout - at other moments, the text will betray its social standing, since we cannot remake our social standing simply by adopting alternative idioms. Put differently, social standing manifests an advocate's inability to control fully their discourse, since meaning emerges through a constellation of factors. On this score, we may recall Derrida's prescription that textual analysis should produce a signifying structure constitutive of a text between what one as a speaker or writer "commands and what [one] does not command of the patterns of the language that [one] uses." ${ }^{25}$ Public sphere scholars may exploit this tension to discern privilege.

Further, we may seek out privilege by considering the potential of calls for counterpublicity to expand or constrict public discourse. Insofar as counterpublics successfully circulate their alternative discourses among wider publics, they add to the possible range of participants and discursive practices in a given society. With respect to a feminist counterpublic sphere, for example, Felski explains that feminism "as a critique of values is also engaged in a more general and public process of revising or refuting male-defined cultural and discursive frameworks." ${ }^{26}$ A feminist counterpublic sphere does not seek to achieve gains for women at the expense of male advocates, but to circulate alternative frameworks that enable women and men to engage in democratic discourse and deliberation. Counterpublic theorists have recognized that discourses can carry varying public import, such that hate speech may circulate an alternative interpretation of race relations, but its success would limit the opportunities of members of minority groups to engage publicly.

This example underscores the need to consider calls for counterpublicity in the context of the public sphere as a network of partially intersecting and overlapping, directly and indirectly connected, sites of discourse. In this spirit, Gerard Hauser writes: "The contemporary public sphere has become a web of discursive arenas, spread across society and even in some cases across national boundaries." ${ }^{27}$ From this perspective, developments at one node in the network affect others, even if participants across discursive sites are unaware of each other. ${ }^{28}$ Attempts to silence others diminish the democratic quality of a public sphere, and reveal a desire for (if not the attainment of) privilege. My point is not to embrace the traditional liberal position that more speech equals better speech, since we may hope for hate speech to diminish when advocates engage wider publics to affirm, for example, the loving and decent character of same-sex unions. Rather, my point is to consider 
how counterpublicity may be invoked cynically to marginalize others. Further, in considering the implications for discursive space, we need to reaffirm the relational quality of discourse and its material conditions. Widening or narrowing discourse does not result simply from the circulation of texts, but also draws on the structural, institutional, and societal forces that facilitate circulation. Money, connections, organization, access, and other factors help some groups achieve a loud voice in the public sphere while others are heard by many citizens as a whisper.

\section{The Rise of a Conservative Counterintelligentsia}

Issuing a prominent call for counterpublicity, William Simon participated in an orchestrated movement initiated by public officials and private executives in the early 1970s to overcome the perceived marginalization of conservative policy ideas. Despite the election of Richard Nixon as president, influential social actors believed that conservatism continued to suffer from a marginalization effected through the formation of the New Deal policymaking coalition in the 1930s. These individuals believed that conservatism could not turn to established sources of intellectual activity for assistance, because universities and foundations were controlled by liberals. Instead, conservatism had to develop resources from within and build a counterintelligentsia that could promote conservative principles on equal footing. ${ }^{29}$ The effort would require new ideas and directed financial resources.

Conservatives began to issue a call to action in a series of influential documents that appeared in the 1970s. One such document was a 1971 memorandum written for the US Chamber of Commerce by Lewis F. Powell Jr. two months prior to his nomination to the Supreme Court by President Nixon. The memorandum outlined threats facing capitalism from various segments of American society and prescribed some means of redressing this situation. Insisting that the "American business executive is truly the "forgotten man," Powell maintained that "few elements of American society today have as little influence in government as the American businessman, the corporation, or even the millions of corporate stockholders." 30 The various social movements of the 1950s and 1960s had forced open the doors of government to many of those on the margins of society, but business had no champion. Liberals and reformers had adopted a language of rich versus poor, which amounted to reckless demagoguery.

An effective response required the coordinated efforts of business. Powell identified several fronts on which business could wage this campaign. First and foremost was the need to address the campus origins of the hostility toward business. Powell recommended that the Chamber of Commerce assemble a highly qualified staff of social scientists to counter the ideas emanating from the nation's universities. He also called for the establishment of a speaker's bureau to be heard on campuses and elsewhere. In addition, he instructed the chamber to review textbooks for bias and to establish links with potential campus allies in business schools and other settings. Off campus, the chamber needed to direct its attention to the media and government. Powell believed that business could benefit by monitoring the media and seeking to 
influence the government. Business leaders needed to develop and use political and financial power in a determined fashion.

Calls for a conservative counterintelligentsia appeared during a period of increasing economic uncertainty and anxiety. By the mid-1970s, the long, virtually unbroken post-World War II economic boom that had strengthened the US economy came to an end. Between 1948 and 1972, the real median family income more than doubled. Increased worker productivity fueled a growing economy, and a growing economy provided greater resources for social programs. After 1972, real median income stalled and then fell. In 1980, the US suffered the largest single decline in real median family income - 5.5\% - since the government began keeping records of this statistic in 1947. ${ }^{31}$ The 1970s also witnessed stagflation: simultaneous inflation and economic stagnation. Stagflation confounded accepted Keynesian approaches to macroeconomic policy. Inflation and unemployment increased in tandem, while wage increases for employed workers could not keep pace with the rising cost of living. ${ }^{32}$ The economic disruptions of the 1970s returned many Americans to an "older psychology of scarcity," as gas lines prompted by the oil embargo of 1973 provided dramatic, historically-tinged evidence of the end of unlimited consumption of resources. $^{33}$

In this climate, Americans' distrust of government grew-a sentiment encouraged by Simon's ideological cohorts. In 1969, President Richard Nixon announced a "New Federalism" to redirect tax revenues and decision-making from the federal government to the states. For Nixon, a new delegation of responsibility was absolutely necessary: the nation faced "a crisis of confidence in the capacity of government to do its job." And the explanation for this crisis was clear: "A third of a century of centralizing power and responsibility in Washington has produced a bureaucratic monstrosity, cumbersome, unresponsive, ineffective." ${ }^{34}$ In part, this crisis arose from the conduct of the Nixon administration and its predecessor. Public officials charged with waging the Vietnam War, including Presidents Johnson and Nixon, appeared less than forthcoming in their public statements about its progress. The Watergate scandal compounded these concerns. ${ }^{35}$ Although Watergate involved wrongdoing by members of one political party, it sent a larger message that politicians would place themselves above the law when doing so enabled them to obtain political advantage. If politicians behaved cynically toward the institutions they supposedly revered, then citizens could not be expected to trust these institutions. In 1979, President Jimmy Carter again warned of crisis, tying together the economy and the national psyche. Carter discerned a "crisis of confidence" that "strikes at the very heart and soul and spirit of our national will. We can see this crisis in the growing doubt about the meaning of our own lives and in the loss of a unity of purpose for our Nation." 36

Calls to reassert the marginalized voice of the businessperson drew on a long tradition of laissez-faire economic thought promoted prominently by economists at the University of Chicago. The "Chicago School" surrogates advanced a consistent conceptual program: insistence on an unfettered, individual-oriented market; the association of individual liberty and capitalism; the revival of neo-classical economic 
theory; the widespread application of market-based approaches to social problems; the modeling of political behavior through economic behavior; and, according to some observers, the conflation of the actual market with an ideal market. ${ }^{37}$ In 1962, Milton Friedman attracted national popular attention to this perspective with the publication of Capitalism and Freedom. Individualism and freedom appeared as paramount values in his book, enabling a series of associations and oppositions. Friedman equated the individual and freedom with the market and choice. He opposed these values to a second cluster centered on the government, which invoked conformity, constraint, and coercion. Friedman formulated an atomistic view of society in which individuals appeared as discrete and complete entities. In an atomistic society, government could act properly only as an umpire. Individuals alone knew their interests and preferences, and they revealed these interests and preferences through their actions in the market. Friedman held that the market "permits unanimity without conformity ... it is a system of effectively proportional representation. On the other hand, the characteristic feature of action through explicitly political channels is that it tends to require or to enforce substantial conformity." 38

In response to calls by Powell, Simon, and others, a number of conservative think tanks emerged to become significant players on the national policymaking scene. Some were formed in the 1970s; others had existed before, but had constituted a scarcely perceptible presence in the policymaking arena. Three think tanks merit specific attention: the Heritage Foundation, the Cato Institute, and the American Enterprise Institute.

The Heritage Foundation, which Simon served as a board member, was established in 1973 by conservative activists led by Paul Weyrich. The Heritage Foundation received important early financial support from Joseph Coors and John Scaife. Coors gave an initial gift of $\$ 250,000$, and Scaife initially contributed $\$ 900,000$. To generate additional funds, Heritage created a strong direct mail system. By 1983, 34\% of its revenues came from direct-mail solicitations. By 1990, this figure had increased to $52 \% .^{39}$ The Heritage Foundation adapted quickly to the demands of Washington policymakers. Its president, Edwin Feulner, judged the foundation's policy briefs on what he called "the brief-case test": "[A]nalyses and recommendations should be as concise as possible, able to be read and absorbed in a limousine on the way to a meeting." ${ }^{\prime 4}$ With the election of Ronald Reagan as president, the Heritage Foundation asserted itself prominently in the policymaking spotlight. The foundation presented the Reagan transition team with the monumental volume Mandate for Leadership. Over 300 contributors helped to produce the 1,093-page document, which addressed policy areas from all cabinet departments, several independent regulatory agencies, and other government agencies. ${ }^{41}$

Another influential think tank to emerge during this period was the American Enterprise Institute (AEI). Founded in 1943, the AEI operated on a modest scale for much of its early history. Its president William Baroody sought to raise the stature of the AEI in the mid-1950s, which resulted in a steady increase in staff and budget resources. In his pitch to potential donors, Baroody invoked appeals that Powell and Simon would popularize in the 1970s. He claimed that conservative ideas "were 
locked out of the policy dialogue." 42 In the early 1970s, the AEI expanded significantly as a result of a \$25 million capital campaign launched in 1971 by Melvin Laird, a longtime supporter who served as secretary of defense at the time. As a consequence of this campaign, the AEI's annual budget increased from \$1 million in 1970 to $\$ 10.4$ million in 1980. Its staff increased during this period from 19 to 135 people. During the Carter administration, the AEI became an important site of conservative policy opposition. Former President Gerald Ford became an AEI distinguished fellow, as did some of his cabinet secretaries - including Simon - and other high-ranking administration officials.

A third influential think tank that grew during this period was the Cato Institute. Formed in San Francisco in 1977, the Cato Institute moved to Washington in 1981 and steadily increased its prominence among policymakers. Libertarian principles guided the Cato Institute. Its founder and long-serving president, Edward Crane, served as national chair of the Libertarian Party in 1974. Increasingly skeptical about the prospects for a major third party in the US, Crane generated the idea for a libertarian think tank in the mid-1970s. He then persuaded oil and petrochemical heir Charles Koch to fund the organization. At times, the consistent libertarianism of the Cato Institute, which has included support for such positions as marijuana legalization, has produced disagreements with culturally-minded segments of the conservative movement. However, the Cato Institute's influence has continued to increase.

The rise of conservative think tanks represented a convergence of ideas, marketing, and money. Supporters of conservative think tanks believed that they had to discuss ideas and principles directly. Advocates like Powell and Simon believed that conservatives had to develop ideas to counter liberal ideas. Moreover, they believed that their ideas would resonate with Americans. Conservatives marketed these ideas skillfully. William Baroody Jr., president of the American Enterprise Institute from 1978 to 1986, acknowledged the use of marketing techniques unapologetically: "I make no bones about marketing.... We pay as much attention to dissemination of the product as to the content." ${ }^{33}$ AEI and others devoted sizeable budgets and staff to public relations. Conservative think tanks quickly made their experts readily accessible to the media. They also created multiple "feedback loops" between Congress and the news media to increase the circulation of their ideas. ${ }^{44}$ Of course, money facilitated these activities. Since the early 1970s, conservative foundations have substantially increased their funding of like-minded think tanks. ${ }^{45}$ Additionally, conservative foundations have strategically targeted these organizations, providing recipients with general operating funds rather than project-specific funds, thus increasing flexibility and ensuring long-term financial stability.

\section{Investigating Counterpublicity and Privilege}

In A Time for Truth, William Simon issued a call for counterpublicity and signaled his own privilege, belying claims of marginalization and exclusion. How did this former Wall Street banker, treasury secretary, and foundation president cast himself and 
other businesspeople as marginalized? Simon argued that businesspeople suffer at the hands of a liberal ruling elite that could control American society, directing the lives of others to augment its own power. Fundamentally anti-democratic, this ruling elite frames its aspirations in terms of achieving a greater social good. Simon held that the ruling elite "combines a morbid economic ignorance with a driving power lust, and it combines hostility to democracy with the illusion that it speaks for the People."46 Controlling education, government, and the media, it constituted a "dictatorship" that utilized the police powers of the state "not to protect individual liberty, but to violate it." 47 Still, liberal intellectuals could not, by themselves, control American society. To achieve their hegemonic position, the elite had formed an effective alliance with segments of the middle class - who received patronage in the form of jobs and other material benefits - and, tragically, businesspeople and conservative politicians. Propelled by a desire for "respectability" and a lack of courage, businesspeople and politicians acquiesced to liberal demands and character assassination:

[W] hen the liberals orchestrate a nationwide uproar over good versus evil, all those defined as evil suffer an acute loss of nerve.... And whatever they may think and say in private, in public they either go mute or stumble frantically over their own feet as they rush to join the moral bandwagon. ${ }^{48}$

In resisting the ruling elite, Simon stood nearly alone.

To justify their rule, the elite propagated a disastrous transfiguration of equality into egalitarianism and demanded adherence to this orthodoxy. On this score, Simon appealed directly to the nation's beginnings. He held that the Founding Fathers embraced the idea of equality, which meant: "[M]en should share an equal opportunity to face the challenges of life, each free to achieve what he could and rise to the level he could by his own wit, effort, and merit." 49 Equality promised only opportunities, enabling individuals to employ their "wit, effort, and merit" efficaciously. Sadly, the ruling elite rejected equality, enforcing egalitarianism as the ruling value. Egalitarianism threatened individual liberty by "perceiv[ing] men, ideally, as interchangeable units and seek[ing] to deny the individual differences among them." ${ }^{50}$ Ordinary citizens existed in liberals' view only as a means to an end. Objecting to this vision placed Simon on the margins of society; he insisted:

[I]t is the economics and the philosophy of capitalism which represent "dissent"dissent from a dominant socialist-statist-collectivist orthodoxy which prevails in much of the media, in most of our large universities, among many of our politicians and, tragically, among not a few of our top business executives. ${ }^{51}$

Resisting the liberal elite, Simon depicted himself as a brave, heroic truth-teller willing to sacrifice his personal well-being for the good of the nation. Dismissing the counsel of "friends" who regularly urged him to moderate his discourse-both for his own well-being and for the strategic success of his party-Simon contended that the grave threats facing the country necessitated risk. Simon recounted: "[O]ne day after a particularly bitter confrontation with White House 'pragmatists,"” he told his wife, "If they get me, they get me. But at least I'll know I was right." 52 Simon was not oblivious to the dangers, but he had to act courageously to save the nation. In 
campaigning against growing federal budgets, Simon insisted, "I took that abuse not because I was a Fearless Fosdick but because I was so much more frightened by deficit spending and its power to devastate an economy and a society." 53 The gravity of the situation inspired Simon's heroics.

In waging his battle against the ruling elite, Simon invoked the truth as a potent weapon. For all its power, the ruling elite could not overcome the contradictions of its ideology. The ruling elite spoke in an idiom of democracy, but their positions still produced alienation. Rejecting the counsel of those who "incessantly instructed [him] to 'tone down my rhetoric,'” Simon retorted, "I was not dispensing 'rhetoric', and I did not modulate my voice. I knew something these advisers did not know: that my chosen 'constituency' was hearing me." 54 Simon's disavowal of rhetoric suggests that he contrasted his truthful statements to others distorted by the effects of language. In this way, Simon exhibited a realist discursive style, which, according to James Aune, "is the default rhetoric for defenders of the free market." These advocates treat language as a veil over nature. Truth may be gleaned by progressively uncovering symbolic elements until one locates an essence. Aune writes: "[T]he realist economic style works by radically separating power and textuality, constructing the political realm as a state of nature, and by depicting its opponents as prisoners of verbal illusions." 55 Once language is compared to a divergent reality, illusions may be combated and truth restored. In this way, although Simon occupied a perilous position, his advocacy threatened the elite's reign, for he possessed both the knowledge and the willingness to unmask their ideology.

Commitment to a particular notion of "freedom" guided Simon's opposition to the ruling elite. First, Simon defended an exclusively negative sense of freedom. He held that freedom, properly understood, indicated not "a presence but an absence - an absence of governmental constraint." ${ }^{\prime 56}$ In a free society, citizens could not be made to do things against their will. Freedom consisted of the ability of citizens to pursue their interests and desires without government coercion. However, in rejecting freedom as a presence, Simon rejected positive notions of freedom. Positive freedom could encompass government actions geared toward developing capabilities among citizens so that they may achieve their interests and desires. The gesture here is to Isaiah Berlin's contrasting tension between negative and positive liberty:

It is this, the "positive" conception of liberty, not freedom from, but freedom toto lead one prescribed form of life - which the adherents of the "negative" notion represent as being, at times, no better than a specious disguise for brutal tyranny. ${ }^{57}$

Second, Simon insisted on an intrinsic connection between economic and political freedom. He explained his motive for writing A Time for Truth as raising "national awareness of the connection between economic and political freedom. The connection is real and unbreakable. To lose one is to lose the other." 58 Asserting this link, Simon implied an ultimate commensurability between economic and political questions. Potential conflicts between questions of efficiency and justice, for example, could be adjudicated by a unitary value of freedom, and standards of selfinterested behavior could be transferred unproblematically from the market to 
politics. This linkage further transfigured the economic concerns of businesspeople into political threats facing the nation: "A nation that decreases its economic freedom must be less politically free." ${ }^{59}$

Simon's articulation of freedom also held implications for relations among citizens and national identity. Drawing these themes together, Simon imagined the nation as an aggregation of autonomous individuals. Reiterating the connection between economic and political freedom, he maintained: "The free market is nothing but the sum of these interacting individual decisions. It is the most individualistic and most democratic economic system conceivable." ${ }^{30}$ As the repetition in this passage suggests, Simon attributed freedom to individuals and denied a collective sense of freedom. Indeed, collectivism exclusively promoted coercion, and any effort to balance individual and collective goals necessarily eclipsed individual freedom. Individualism and collectivism constituted "polar systems of political-economic organization" that presented policymakers with a clear choice. Simon insisted: "[T] hose nations that have sought a genuine mix of the polar opposites of a free and an unfree economy ... are slowly deteriorating or rapidly rotting." ${ }^{.11}$ While Simon warned of European nations pursuing this dangerous path, he expressed outright alarm at similar developments in the United States, since this constituted a repudiation of national identity: "America is tied to its original political and economic arrangements because they were the definition of America." ${ }^{62}$ In this way, Simon cast alternative understandings of freedom as fundamentally anti-American.

However, Simon's articulation of freedom circumscribed the freedom of others, thereby signaling an aspect of privilege in his call for counterpublicity. Embracing an exclusively negative notion of freedom and insisting on an unbreakable link between economic and political freedom served to limit the context for understanding human agency and frustrate government attempts to redress inequalities. With respect to context, Simon highlighted individual behaviors while ignoring situational constraints; he represented citizens as free market actors who, prior to the increasingly intrusive policies of government, could act as they pleased. However, differences in resources, power, and social standing among publics and counterpublics afford greater freedom to some individuals than others. In this way, Simon's view of freedom justified varying degrees of unfreedom. Moreover, economic success served as a proxy for political interest and ability. Simon thus urged his readers to disavow the liberal association of poverty and virtue. Conceding that poverty sometimes resulted from "honest misfortune," he nevertheless linked poverty to "sloth, incompetence, and dishonesty." ${ }^{\prime 3}$ This equation implied that poor people had not exercised their freedoms, whereas wealthy people took full advantage of their free agency.

Although Simon explicitly opposed individual freedom and collective coercion, his authorial persona exhibited a commitment to collective goals and shared freedoms. Of course, at the propositional level, he denied the very existence of collective social entities, asserting: "There is no such thing as the People; it is a collectivist myth. There are only individual citizens with individual wills and individual purposes." ${ }^{\prime 64}$ This statement comported with Simon's view of freedom, since non-existent entities 
could not uphold political values. And yet his self-presentation as a brave truth-teller expressed a strong degree of sacrifice - not for his own sake, but for the greater good. Whereas other businesspeople and members of his own party capitulated to liberal demands, Simon fought against the ruling elite so that the nation could survive. He expressed "fear for the country," subjecting himself to the duplicity and derision of Washington insiders to restore the "economic health of the nation." ${ }^{65}$ In these cases and others, "country" and "nation" signified collective entities, and Simon's sense of duty implicated something beyond individual purpose. Given his financial acumen, Simon could have followed the path of his peers and lived comfortably amid the ruling elite: fighting for "freedom" imperiled his individual well-being. Further, Simon's linkage of freedom and identity, which he traced to the nation's founding, invoked a collective identity. He wrote: "America was born a capitalist nation.... [T] his capitalist, or free enterprise, identity is true of no other nation." 66 Freedom forged an American identity that all citizens shared. Simon understood his individual identity in terms of this imagined origin, and he sought to remind his readers of this shared heritage.

A Time for Truth also exhibited textual markers that betrayed Simon's privileged social position. Conspicuous among these was his call for a "massive and unprecedented mobilization of the moral, intellectual, and financial resources" necessary to support a counterintelligentsia and save the free-enterprise system. ${ }^{67}$ Moral and intellectual resources may be fairly well distributed across publics and counterpublics, but finances skew towards the top. Few advocates could expect a positive response from audiences to a call to "rush [their money] by multimillions to the aid of liberty." ${ }^{68}$ For his part, Simon issued this call matter-of-factly. His passion focused on persuading businesspeople to relinquish their dangerous desire for respectability among the ruling elite, but he never doubted their capacity to generate funds. Further, Simon's casual references to various political figures evidenced strong political connections. He shared a laugh with the French finance minister over the political grandstanding of Washington and New York politicians; he recounted a playful, discreet wink from his "good friend" Hubert Humphrey who "got a prankish pleasure, however, out of denouncing me publicly during the New York [financial] crisis [of the mid-1970s]." 69 In terms of financial and institutional authority, he addressed an audience that was well positioned, even as it may have identified with his claims of marginalization, to carry out his agenda.

More subtly, as he recalled interactions with policymakers and opinion leaders, Simon's self-presentation evidenced a patrician background and bearing. In various encounters, he appeared as a voice of civility and graciousness, while his interlocutors exhibited rudeness and coarseness. Moreover, he often expressed offense when confronting what he regarded as violations of decorum. Recounting testimony before the Agriculture Committee of the House of Representatives, Simon placed himself amid a barn-like setting noting that the committee chair, Rep. Poage, spoke with a “startling high, shrill voice, like a mouse's scream." Further, according to Simon, the 
committee members constantly ate peanuts (a subsidized crop) during hearings, since agricultural firms supplied them for free:

While I was testifying and they were talking [to each other], they were also ripping open their cellophane bags before the open mikes, and ferocious cracklings and chompings were compounding the furor. Running like a crazy counterpoint through the entire racket was the incessant squeaking of Congressman Poage. ${ }^{70}$

While the committee members appeared as animals, Simon remained calm, collected, and reasonable.

Simon depicted himself, in these and other moments, as patiently suffering the ridiculousness, ignorance, and, in some cases, cruelty of policymakers. In one instance, Simon noted that he accidentally cut his forehead on the door of his car as he rushed to a Ways and Means Committee hearing. After consulting a nurse, he called the committee chair to explain that his injury required immediate medical attention. Unmoved, the committee chair demanded that he proceed immediately to the Capitol. Simon expressed indignation at such gross insensitivity: "I was there for about five hours, bleeding incessantly, in considerable pain and facing Congressmen who were screaming and yelling." He denounced the "sheer brutality of keeping me there for hours while blood was dripping from my head." ${ }^{\text {,1 }}$ Once more, he portrayed himself as calm and reasonable, while policymakers - who screamed and yelledwere irrational, incapable of following even basic rules of civility. As his indignation implied, Simon obeyed the rules of polite society and expected others to do the same. He shared the comments of a lone sympathetic committee member, who wondered "why I, a man of independent means, put up with such treatment."72 With "independent means" modifying its subject, this statement indicated that Simon possessed a choice unavailable to other counterpublic advocates: he could return to a comfortable private life without suffering personally from the committee's decisions. Furthermore, this statement suggests that "independent" witnesses should not expect hostile treatment from the committee whereas "dependent" witnesses should not complain.

Although he depicted himself as a brave truth-teller, Simon expressed offense when he received negative coverage in the press. For instance, he bemoaned the way in which he was characterized during New York City's threatened bankruptcy in the mid-1970s as a cruel and heartless figure. "If I stress this," he explained, "it is not merely because I was hurt by it-I was - but because it was as serious a piece of mischief-making by the press as I have yet experienced." ${ }^{\text {,73 }}$ In casting Simon as a villain, the press ignored the real causes of the financial crisis, responding to his recommendations with "personal invective: I was either 'inhumane' or 'Simple Simon." "74 We could interpret these passages as Simon being thin-skinned, which certainly would not be confined to advocates speaking from positions of privilege. Any public figure may exhibit an acute sensitivity to negative press coverage. However, the reasons driving Simon's "hurt" feelings appeared to be related to respect and reputation. Simon implied that the press had not treated him in a properly respectful manner, and he wished to maintain his reputation among Wall Street 
bankers and Washington policymakers. This constellation of audiences betrayed Simon's social standing as someone well placed in financial and political circles.

Although Simon claimed that businesspeople and like-minded intellectuals suffered exclusion from discursive forums, his program for a counterintelligentsia threatened to exclude the voices of others, thereby reducing rather than expanding discursive space. This possibility surfaced in his argument against putatively ameliorative state action: "[T]here must be a conscious philosophical prejudice against any intervention by the state into our lives, for by definition such intervention abridges liberty." 75 This claim displayed the rhetorical power of definitions, which, as Edward Schiappa notes, "represent claims about how certain portions of the world are." Schiappa maintains that definitions influence "our understanding of the world and the attitudes and behaviors we adopt toward various parts of the world."76 In the process, definitions mask their rhetorical character, since we may interpret our world differently and glean alternative prescriptions for action. In this way, as David Zarefsky notes, definitions may foreclose deliberation by asserting positions that ought to be justified explicitly. ${ }^{77}$ Definitions may accomplish the rhetorical work of more extended deliberative encounters, but they do so without providing interlocutors with opportunities for critical examination and reflection.

Simon utilized dissociation in his definition to comport laissez-faire governance with his negative view of freedom. Zarefsky explains that definition by dissociation "consists of breaking a concept into parts in order to identify one's proposal with the more favored part."78 State intervention constituted an abridgement of liberty only if readers viewed freedom as absence, but US political history provides numerous examples of freedom as both absence and presence, as exemplified in FDR's "four freedoms," which included "freedom from want" and prescribed ameliorative government action to achieve it. Not surprisingly, Simon disparaged FDR as the original promulgator of the dangerous philosophy of egalitarianism, "corrupting" the concept of freedom so thoroughly that "succeeding generations were never again clear as to what it meant." ${ }^{\text {"79 }}$ This assessment cast aside particular perspectives as unAmerican and unworthy of deliberative engagement. Simon sought identification with a particular history, denying alternative pasts and the identities they engendered.

Just as Simon did not subject his fundamental value of negative freedom to critical scrutiny, he did not acknowledge the salience of potentially competing values. Outlining his agenda for a counterintelligentsia, Simon insisted that its "overriding principle" must establish "individual liberty [negative freedom] as the highest political value - that value to which all other values are subordinate and that which, at all times, is to be given the highest 'priority' in policy discussions." ${ }^{\text {" }}$ "This assertion narrowed discursive space in at least two ways. First, Simon's elevation of individual liberty as the supreme value de-historicized its use and hypostatized its meaning. As John Dewey argued in Liberalism and Social Action, political values obtain their meaning and application from particular situations; as times change, so, too, do the meaning and significance of our political values. ${ }^{81}$ Insisting on a particular interpretation of freedom as preeminent, Simon denied others the opportunity to assess its use in contemporary American society. Second, Simon discounted the 
pluralistic character of American society, in which different groups appeal to diverse political values. Considered in this light, Simon's embrace of liberty represented a particular value as universal. Whereas businesspeople might have been satisfied with laissez-faire governance, others might have championed justice or equality as primary public values. In this way, Simon committed the very crime he charged the ruling elite with perpetrating: "The American citizen must be made aware that today a relatively small group of people is proclaiming its purposes to be the will of the People." 82 Expanding discursive space would entail recognizing the potential for value conflicts in a pluralist society, and welcoming the adjudication of these conflicts through public engagement.

\section{Conclusion}

William Simon's call for counterpublicity raises important questions regarding the relationship among counterpublic, ideology, and materiality. Assessing this relationship requires public sphere scholars to balance potentially conflicting impulses: we cannot simply dismiss Simon because of his background, and neither can we accept unreflectively his claim of marginalization. Instead, we may critically engage his call (and similar cases) by considering how he signaled his own privilege. I have outlined three ways of doing so. First, we may foreground key values in texts to consider whether an advocate upholds or betrays these values. Simon professed an undying commitment to freedom, but his articulation of a negative freedom discounted the constraints on human agency that afford greater freedom to some people than to others. Further, Simon's willingness to sacrifice his well-being for what he regarded as the good of the country intimated a collective sense of freedom and identity that he explicitly denied. Second, since no speaking position is neutral, we may examine a text for markers of social standing. Simon's plan for a conservative counterintelligentsia drew on substantial financial and institutional resources, and his selfpresentation suggested a patrician background and bearing. Third, we may assess whether an advocate, in issuing a call for counterpublicity, would restrict or expand discursive space for others. Simon's call threatened to restrict discursive space by asserting, rather than arguing for, his preferred governing philosophy and by elevating negative freedom as the preeminent political value, which ignored the complexities of a pluralist society.

My focus on privilege may advance our understanding of the dynamics of marginalization, which figures prominently in conceptions of counterpublicity. Often, these terms exhibit an inverse relationship, marking social hierarchies and relations of power among publics and counterpublics, as Robert Hariman suggests: "[A]s superior status is a condition of social privilege, so inferior status is a condition of social marginality." 83 Appreciating this relationship, we also need to recognize that a multiple public sphere frustrates efforts to place privilege and marginalization along a single continuum or in a center-periphery model. Instead, if we regard a multiple public sphere as a network, we can recognize some nodes as more prominentsustaining more connections in the network - than others. Such nodes may function 
centrally in the operation of the network, providing greater access to symbolic and material resources, without constituting a "center." At the same time, particular nodes may exhibit both marginalization and privilege in their varying connections to other nodes. For example, some conservative think tanks may be comparatively more marginalized than others, even as they exhibit greater influence in policymaking forums than, say, poor people's advocacy groups. These unavoidable complexities do not undermine the project of critical theory, since we can still access how relative advantage and disadvantage facilitate differential opportunities for engagement among publics in a multiple public sphere.

As we pursue these inquiries, we should maintain the fluidity of public sphere theory while affirming its status as a critical theory. Indeed, recognition of fluidity is one of the important contributions of the discursive emphasis in our theorizing of publics. Through discursive engagement, individuals and groups construct identities, shape needs and interests, and build forums and networks, among other activities. To sustain this scholarship, "counterpublic" cannot become an analytic category that contains some groups and expels others. To illuminate discourse in the public sphere, a counterpublic should tell us something beyond summarizing an advocate's claims. Towards this end, I have advanced a perspective that provides a normative framework while avoiding a priori judgments. Our goal should not be to decide who may or may not claim counterpublicity, but how invocations of counterpublicity serve various interests and agendas.

We should recognize, too, that no call for counterpublicity is inherently pure. Although differently situated in the networks of the public sphere, progressive advocates may also betray their values, enjoy particular forms of privilege, and restrict the discursive space of others. For example, Floyd Anderson and Lawrence Prelli argue that Frankfurt School critical theorist Herbert Marcuse imagines a restricted public sphere in his celebrated 1960s counterculture text One-Dimensional Man that seeks to replace the instrumentalist reason of capitalist society with a similarly narrow Hegelian idealist reason. ${ }^{84}$ Whether or not we agree with this critique, it reminds us of the need to engage critical theory self-reflectively. As Della Pollock and J. Robert Cox suggest, critical theory must be "the subject of intense skepticism, doubt, and scrupulous attention to error; and it must be met with passionate commitment to a more satisfactory alternative." 85 The impossibility of a pure, innocent position should not dissuade public sphere scholars from pursuing the emancipatory aims of our theory. In this way, we may contribute to a more vibrant public sphere.

\section{Notes}

[1] In his important book Selling the Free Market, James Aune analyzes the rhetoric of freemarket intellectuals and politicians, respectively, but he does not discuss "cross-over" figures like Simon, and neither does he address in detail the growth of think tanks in the resurgence of conservative policy initiatives. See James Arnt Aune, Selling the Free Market: The Rhetoric of Economic Correctness (New York: Guilford Press, 2001).

[2] See, e.g., Robert Asen and Daniel C. Brouwer, eds., Counterpublics and the State (Albany: State University of New York Press, 2001). 
[3] Nancy Fraser, "Rethinking the Public Sphere: A Contribution to the Critique of ActuallyExisting Democracy," in Habermas and the Public Sphere, ed. Craig Calhoun (Cambridge: MIT Press, 1992), 109-42.

[4] See Oxford English Dictionary, s.v. "Privilege," http://www.dictionary.oed.com/entrance.dtl/.

[5] I am grateful to Dan Brouwer for this insight.

[6] For a discussion of attention to ideology in rhetorical studies, see Dale Cyphert, "Ideology, Knowledge, and Text: Pulling at the Knot in Ariadne's Thread," Quarterly Journal of Speech 87 (2001): 378-95. For a discussion of ideology in the tradition of critical theory, see Terry Eagleton, Ideology: An Introduction (London: Verso, 1991).

[7] Chantal Mouffe, The Democratic Paradox (London: Verso, 2000), 98, 100, 103.

[8] Chip Berlet and Matthew N. Lyons argue that a "classic subversion myth" of "innocents captured by barbarians" ties together the Old Right and New Right, informing their opposition to communism, civil rights, Black power, contemporary educational curricula, feminism, gay rights, and more. Chip Berlet and Matthew N. Lyons, Right-Wing Populism in America: Too Close for Comfort (New York: Guilford Press, 2000), 199-227. Jean Hardisty argues: "A reactionary protest movement seeks to restore a previous period, one that is usually seen as a better, more peaceful, and more secure time." Jean Hardisty, Mobilizing Resentment: Conservative Resurgence from the John Birch Society to the Promise Keepers (Boston: Beacon Press, 1999), 9. Counterpublics and social movements are not synonymous, although they may exhibit connections. Simon, for instance, issued his call for counterpublicity amid an emergent conservative intellectual movement.

[9] Kristy Maddux, "When Patriots Protest: The Anti-Suffrage Discursive Transformation of 1917," Rhetoric and Public Affairs 7 (2004): 304-5.

[10] Shalini Randeria, "De-politicization of Democracy and Judicialization of Politics," Theory, Culture and Society 24 (2007): 40-41. In this spirit, holding that neoliberal policy prescriptions ignore the "social costs" of economic decisions, Pierre Bourdieu argues: "All the critical forces in society need to insist on the inclusion of the social costs of economic decisions in economic calculations." Pierre Bourdieu, Acts of Resistance: Against the Tyranny of the Market, trans. Richard Nice (New York: New Press, 1998), 39.

[11] Slavko Splichal, "Why Be Critical?" Communication, Culture and Critique 1 (2008): 25.

[12] Relations between rhetoric and materiality have been a longstanding interest in rhetorical scholarship. For a sense of the development of this literature, see Michael Calvin McGee, "A Materialist's Conception of Rhetoric," in Explorations in Rhetoric: Studies in Honor of Douglas Ehninger, ed. Raymie E. McKerrow (Glenview, IL: Scott, Foresman, 1982), 23-48; Raymie E. McKerrow, "Critical Rhetoric: Theory and Praxis," Communication Monographs 56 (1989): 91-111; Dana L. Cloud, "The Materiality of Discourse as Oxymoron: A Challenge to Critical Rhetoric," Western Journal of Communication 58 (1994): 141-63; Ronald Walter Greene, "Another Materialist Rhetoric," Critical Studies in Mass Communication 15 (1998): 21-41; Carole Blair, "Reflections on Criticism and Bodies: Parables from Public Places," Western Journal of Communication 65 (2001): 271-94; Ronald Walter Greene, "Rhetoric and Capitalism: Rhetorical Agency as Communicative Labor," Philosophy and Rhetoric 37 (2004): 188-206; Dana L. Cloud, "The Matrix and Critical Theory's Desertion of the Real," Communication and Critical/Cultural Studies 3 (2006): 329-54.

[13] Michael Warner, Publics and Counterpublics (New York: Zone Books, 2002), 66, 87, 91.

[14] Matthew R. Kerbel and Joel David Bloom, "Blog for America and Civic Involvement," Harvard International Journal of Press/Politics 10 (2005): 3-27; W. Lance Bennett, Christian Breunig, and Terri Givens, "Communication and Political Mobilization: Digital Media and the Organization of Anti-Iraq War Demonstrations in the U.S.," Political Communication 25 (2008): 269-89.

[15] Warner, Publics and Counterpublics, 57, 121-22.

[16] Fraser, "Rethinking the Public Sphere," 122, 123. 
[17] Daniel C. Brouwer, "Communication as Counterpublic," in Communication as ... Perspectives on Theory, ed. Gregory J. Shepherd, Jeffrey St. John, and Ted Striphas (Thousand Oaks, CA: Sage, 2006), 200, 201. See also Constance Chay-Nemeth, "Revisiting Publics: A Critical Archaeology of Publics in the Thai HIV/AIDS Issue," Journal of Public Relations Research 13 (2001): 127-61; Catherine R. Squires, "Rethinking the Black Public Sphere: An Alternative Vocabulary for Multiple Public Spheres," Communication Theory 12 (2002): 446-68.

[18] Cloud, "Matrix and Critical Theory's Desertion," 340.

[19] The role of rhetoric in our understanding of economic conditions has been explicated by Davis Houck in his trenchant analysis of the presidential rhetoric of Herbert Hoover and Franklin Delano Roosevelt. Houck regards rhetoric as "palpable currency: thoughts, beliefs, and emotions constitute and create our economic realities; and markets are propped up on the edifice of discourse." Davis W. Houck, Rhetoric as Currency: Hoover, Roosevelt, and the Great Depression (College Station: Texas A\&M University Press, 2001), 4.

[20] Della Pollock and J. Robert Cox maintain, "Critical theory is above all an historical debate, itself shaped by historical conditions and motivated by various historical interests." Della Pollock and J. Robert Cox, "Historicizing 'Reason': Critical Theory, Practice, and Postmodernity," Communication Monographs 58 (1991): 173.

[21] Nancy Fraser, "Transnationalizing the Public Sphere: On the Legitimacy and Efficacy of Public Opinion in a Post-Westphalian World," Theory, Culture and Society 24 (2007): 8.

[22] Michael Walzer, Interpretation and Social Criticism (Cambridge, MA: Harvard University Press, 1987), 89.

[23] Judith Butler, Undoing Gender (New York: Routledge, 2004), 1.

[24] Linda Alcoff, “The Problem of Speaking for Others," Cultural Critique 20 (1991-1992): 6-7.

[25] Jacques Derrida, Of Grammatology, trans. Gayatri Chakravorty Spivak (Baltimore, MD: Johns Hopkins University Press, 1974), 158.

[26] Rita Felski, Beyond Feminist Aesthetics: Feminist Literature and Social Change (Cambridge, MA: Harvard University Press, 1989), 167-68.

[27] Gerard A. Hauser, Vernacular Voices: The Rhetoric of Publics and Public Spheres (Columbia: University of South Carolina Press, 1999), 71. See also Lewis A. Friedland, Thomas Hove, and Hernando Rojas, “The Networked Public Sphere," Javnost - The Public 13 (2006): 5-26.

[28] Seyla Benhabib writes, "It is through the interlocking net of these multiple forms of associations, networks, and organizations that an anonymous 'public conversation' results." Seyla Benhabib, "Toward a Deliberative Model of Democratic Legitimacy," in Democracy and Difference: Contesting the Boundaries of the Political, ed. Seyla Benhabib (Princeton, NJ: Princeton University Press, 1996), 73-74.

[29] For more detailed discussions of the rise of conservative intellectuals, see Sara Diamond, Roads to Dominion: Right-Wing Movements and Political Power in the United States (New York: Guilford Press, 1995), 178-202; Mark Gerson, The Neoconservative Vision: From the Cold War to the Culture Wars (Lanham, MD: Madison Books, 1996), 73-142.

[30] Louis F. Powell Jr., "Attack of American Free Enterprise System," Media Transparency, August 23, 1971, http://www.mediatransparency.org/storyprinterfriendly.php?storyid=22/. Although he issued his call seven years before the publication of A Time for Truth, Powell did not develop his position as extensively as Simon, and neither did he occupy leadership positions in the growing conservative organizations. Indeed, Powell's subsequent service on the Supreme Court suggests that he may have reconsidered his assessment of the "attack" on the free enterprise system.

[31] Paul Krugman, The Age of Diminished Expectations (Cambridge: Massachusetts Institute of Technology Press, 1992), 2; "Real Income Down 5.5\% in 1980 in a Record Drop," New York Times, August 21, 1981.

[32] Robert B. Barsky and Lutz Kilian, "A Monetary Explanation of the Great Stagflation of the 1970s," National Bureau of Economic Research, http://www.nber.org/papers/w7547.pdf/; Alan S. Blinder, Economic Policy and the Great Stagflation (New York: Academic Press, 1981). 
[33] Michael B. Katz, In the Shadow of the Poorhouse: A Social History of Welfare in America (New York: Basic Books, 1986), 288.

[34] Richard Nixon, "Address to the Nation on Domestic Programs," Public Papers of the Presidents of the United States: Richard Nixon, 1969 (Washington, DC: Government Printing Office, 1971), 637.

[35] For a discussion of Watergate, see Michael A. Genovese, The Nixon Presidency: Power and Politics in Turbulent Times (New York: Greenwood Press, 1990), 171-233.

[36] Jimmy Carter, "Energy and National Goals," Public Papers of the Presidents of the United States: Jimmy Carter, 1979, bk. II (Washington, DC: Government Printing Office, 1980), 1237. For an analysis of the speech, see Dan F. Hahn, "Flailing the Profligate: Carter's Energy Sermon of 1979," Presidential Studies Quarterly 10 (1980): 583-87. For an explication of the societal context of Carter's identification of a "crisis," see Peter N. Carroll, It Seemed Like Nothing Happened: America in the 1970s (New Brunswick, NJ: Rutgers University Press, 1990), 207-32. Before Carter's presidency, Gerald Ford also sought to rouse public support for combating inflation and other economic woes. For an analysis of his rhetoric, see David Gore, "Inflation Rhetoric: Gerald Ford's First Six Months in Office," White House Studies 5 (2005): 215-30.

[37] Robert Leeson, The Eclipse of Keynesianism: The Political Economy of the Chicago CounterRevolution (New York: Palgrave, 2000), 45-72; H. Laurence Miller Jr., "On the 'Chicago School of Economics,"” Journal of Political Economy 70 (1962): 64-69.

[38] Milton Friedman, Capitalism and Freedom (Chicago: University of Chicago Press, 1962), 23. The declarative, ostensibly disinterested quality of Friedman's assertions about the proper roles of markets and governments exemplifies McCloskey's point that economic writing strongly appeals to authority. Adopting the economist's authorial persona, McCloskey writes: "I am also an Economist in command of the best and timeless theorizing on the matter; and if you don't like that, consider that what I assert is anyway true by definition." Deirdre N. McCloskey, The Rhetoric of Economics, 2nd ed. (Madison: University of Wisconsin Press, 1998), 12.

[39] James Allen Smith, The Idea Brokers: Think Tanks and the Rise of the New Policy Elite (New York: Free Press, 1991), 200; David M. Ricci, The Transformation of American Politics: The New Washington and the Rise of Think Tanks (New Haven, CT: Yale University Press, 1993), 161.

[40] Smith, Idea Brokers, 201.

[41] Charles L. Heatherly, ed., Mandate for Leadership: Policy Management in a Conservative Administration (Washington, DC: Heritage Foundation, 1981).

[42] Smith, Idea Brokers, 177.

[43] Quoted in Ricci, Transformation of American Politics, 171.

[44] Jean Stefancic and Richard Delgado, No Mercy: How Conservative Think Tanks and Foundations Changed America's Social Agenda (Philadelphia: Temple University Press, 1996), 143. Underscoring the importance of media access in a European context, Pierre Bourdieu contends, "Thatcherism was not invented by Mrs Thatcher. The ground had been prepared over a long period by groups of intellectuals most of whom wrote columns in the leading newspapers." Bourdieu, Acts of Resistance, 30.

[45] National Committee for Responsive Philanthropy, Axis of Ideology: Conservative Foundations and Public Policy (Washington, DC: National Committee for Responsive Philanthropy, 2004).

[46] William E. Simon, A Time for Truth (New York: McGraw Hill, 1978), 195.

[47] Simon, Time for Truth, 182.

[48] Simon, Time for Truth, 158.

[49] Simon, Time for Truth, 199.

[50] Simon, Time for Truth, 200.

[51] Simon, Time for Truth, 230. 
[52] Simon, Time for Truth, 107.

[53] Simon, Time for Truth, 112.

[54] Simon, Time for Truth, 110.

[55] Aune, Selling the Free Market, 40. Aune draws on Robert Hariman, Political Style: The Artistry of Power (Chicago: University of Chicago Press, 1995). See also McCloskey, Rhetoric of Economics; Roger Backhouse, Tony Dudley-Evans, and Willie Henderson, "Exploring the Language and Rhetoric of Economics," in Economics and Language, ed. Willie Henderson, Tony Dudley-Evans, and Roger Backhouse (New York: Routledge, 1993), 1-20.

[56] Simon, Time for Truth, 19.

[57] Isaiah Berlin, "Two Concepts of Liberty," in Liberty, ed. Henry Hardy (New York: Oxford University Press, 2002), 178. It is not surprising that Berlin, given his liberal philosophy, preferred a negative notion of freedom as better suited to the diversity of human values and ends:

Pluralism, with the measure of "negative" liberty that it entails, seems to me a truer and more humane ideal than the goals of those who seek in the great undisciplined, authoritarian structures the ideal of "positive" self-mastery by classes, peoples, or the whole of mankind. (216)

[58] Simon, Time for Truth, 14.

[59] Simon, Time for Truth, 32. Exploring the linkage of economics and politics in the post-Cold War era, George Cheney considers how advocates often situate markets at "the end of history," espousing "the post-Cold War position that the market has triumphed over socialist and communist economies. With this position, capitalism is usually equated with democracy, such that mentioning one neatly accounts for the other." George Cheney, "Arguing About the Place of Values and Ethics in Market-Oriented Discourses of Today," in New Approaches to Rhetoric, ed. Patricia A. Sullivan and Steven R. Goldzwig (Thousand Oaks, CA: Sage, 2004), 74.

[60] Simon, Time for Truth, 23.

[61] Simon, Time for Truth, 30-31, 40.

[62] Simon, Time for Truth, 43.

[63] Simon, Time for Truth, 220.

[64] Simon, Time for Truth, 221.

[65] Simon, Time for Truth, 10, 107.

[66] Simon, Time for Truth, 42, emphasis added.

[67] Simon, Time for Truth, 229.

[68] Simon, Time for Truth, 230.

[69] Simon, Time for Truth, 166.

[70] Simon, Time for Truth, 57.

[71] Simon, Time for Truth, 61.

[72] Simon, Time for Truth, 62.

[73] Simon, Time for Truth, 154.

[74] Simon, Time for Truth, 155.

[75] Simon, Time for Truth, 218.

[76] Edward Schiappa, Defining Reality: Definitions and the Politics of Meaning (Carbondale: Southern Illinois University Press, 2003), 32.

[77] David Zarefsky, "Definitions," in Argument in a Time of Change: Definitions, Frameworks, and Critiques, ed. James F. Klumpp (Annandale, VA: National Communication Association, 1998), 5.

[78] David Zarefsky, "Presidential Rhetoric and the Power of Definition," Presidential Studies Quarterly 34 (2004): 612. Zarefsky draws on Chaim Perelman and Lucie Olbrechts-Tyteca's discussion of dissociation. Explicating dissociative definitions, Perelman 
and Olbrechts-Tyteca write that a definition "is always a matter of choice," but advocates frequently "claim to have isolated the single, true meaning of the concept." Chaim Perelman and Lucie Olbrechts-Tyteca, The New Rhetoric: A Treatise on Argumentation, trans. John Wilkinson and Purcell Weaver (Notre Dame, IN: University of Notre Dame Press, 1969), 448.

[79] Simon, Time for Truth, 113.

[80] Simon, Time for Truth, 218.

[81] John Dewey, Liberalism and Social Action (New York: G.P. Putnam's Sons, 1935).

[82] Simon, Time for Truth, 221.

[83] Robert Hariman, "Status, Marginality, and Rhetorical Theory," Quarterly Journal of Speech 72 (1986): 38-39. Hariman's essay is not addressed to public sphere scholarship, but his discussion of privilege and marginality illuminates this work.

[84] Floyd D. Anderson and Lawrence J. Prelli, "Pentadic Cartography: Mapping the Universe of Discourse," Quarterly Journal of Speech 87 (2001): 87.

[85] Pollock and Cox, "Historicizing 'Reason," 171. 
Copyright of Quarterly Journal of Speech is the property of National Communication Association and its content may not be copied or emailed to multiple sites or posted to a listserv without the copyright holder's express written permission. However, users may print, download, or email articles for individual use. 